\title{
Correlations between Nutritional Status, Iron Intake, and Fine Motor Development in Infants Aged 6-11 Months
}

\author{
Catur Retno Lestari' ${ }^{1)}$, Harsono Salimo²), Adi Magna Patriadi Nuhriawangsa ${ }^{3)}$ \\ 1)Masters Program in Nutrition, Universitas Sebelas Maret \\ 2)Department of Prediatrics, Faculty of Medicine, Universitas Sebelas Maret/ \\ Dr. Moewardi Hospital, Surakarta \\ 3) Study Program in Animal Husbandry, Faculty of Agriculture, Universitas Sebelas Maret
}

\section{ABSTRACT}

Background: Undernutrition can inhibit growth and development. Specifically, in development, it can change the structure and function of the brain. Fine motor development in infants is affected by many factors such as undernutrition and iron intake. Undernutrition status can occur due to unfulfilled nutritional intake. Iron deficiency can negatively affect fine motor development in children. This study aimed to determine the correlation of nutritional status, iron intake, and fine motor development in infants aged 6-11 months.

Subjects and Method: This was a cross-sectional study conducted at eight Community Health Centers in Kulon Progo Regency, Yogyakarta, Indonesia. A total of 201 infants aged 6-11 months were randomly selected as the sample of the study. The dependent variable was fine motor development. The independent variable was status (Weight/Age). The data on fine motor development were measured by a Prescreening
Developmental Questionnaire (PDQ). The data were analyzed by Chi-square.

Results: Good nutritional status increased fine motor development in infants aged 6-11 months $(\mathrm{OR}=7.12 ; 95 \% \mathrm{CI}=3.03$ to $16.73 ; \mathrm{p}<0.001)$. There was no difference between iron intake and fine motor development $(\mathrm{OR}=0.61 ; 95 \% \mathrm{CI}=$ 0.20 to $1.83 ; \mathrm{p}=0.469$ ).

Conclusion: Good nutritional status increases fine motor development in infants age 6-11 months.

Keywords: fine motor development, nutritional status, iron intake

\section{Correspondence:}

Catur Retno Lestari. Masters Program in Nutrition, Universitas Sebelas Maret. Jl. Ir. Sutami 36A, Surakarta, Central Java, Indonesia. Email: caturretno.lestari@gmail.com.

\section{Cite this as:}

Lestari CR, Salimo H, Nuhriawangsa AMP (2020). Correlations between Nutritional Status, Iron Intake, and Fine Motor Development in Infants Aged 6-11 Months. J Matern Child Health. 05(04): 396-401. https://doi.org/10.26911/thejmch.2020.05.04.06.

cc) (i) (2) Journal of Maternal and Child Health is licensed under a Creative Commons Attribution-Non Commercial-Share Alike 4.o International License.

\section{BACKGROUND}

The nutritional status of children in Indonesia is still a problem. Based on the result of the Indonesian Basic Health Research in 2016, the prevalence of malnutrition and undernutrition, according to the Weight/Age indicator in infants in 2016 was $11.1 \%$. It consisted of $8.0 \%$ undernutrition and $3.1 \%$ malnutrition. However, the prevalence rate in 2015 was $11.9 \%$, consisting of $8.2 \%$ under- nutrition and 3.7\% malnutrition (Susanto, 2019).

Undernutrition can inhibit growth and development. Specifically, in development, it can change the structure and function of the brain. The human brain has extraordinary structural and functional changes from the 24th week until the 42nd week after conception (Santrock, 2011). This development continues from birth to the age of 2 or 3 
years, the fastest period of the first 6 months of life. Therefore, brain cell growth lasts until the age of 3 years (Georgieff, 2008). Undernutrition in children under 2 years of age will cause brain cells to decrease by $15 \%-20 \%$, so that the children will have a brain quality of around 80\%-85\% (Gunawan et al., 2016). Based on the previous studies, the level of fine motor development in children with undernutrition status that was not in line with the age occurred in $66.7 \%$ of children. In addition, the level of motor development in children with the normal nutritional status that was not in line only occurred in $32.8 \%$ of respondents. Based on the result, nutritional status greatly affects motor development in children under five (Kasenda, 2015).

The growth and development in infants are also affected by micronutrient intake such as iron. Therefore, iron deficiency can negatively affect fine motor development in children. Iron deficiency will interfere with the process of myelination. The process of imperfect myelination causes information from the central brain to be slowly received by body cells. Therefore, the body is slow to respond to the information from the brain. Slow body movements in responding to information will disrupt fine motor development in children. Children who are late experiencing important motor events had a significantly decreased myelination rate (Almatsier, 2009). Iron deficiency also negatively affects the functioning of the neurotransmitter system, thus reducing the sensitivity of the dopamine nerve receptors. Decreased density and affinity of dopamine receptors would affect motor performance, cognitive, and behavior (McCann and Ames, 2007). Some of the studies above explain that there was a correlation between nutritional status, iron intake, and gross and fine motor development. However, there were no studies on fine motor development in infants aged 611 months. Therefore, the study on the correlation between nutritional status, iron intake, and fine motor development in infants aged 6-11 months needed to be conducted. This study aimed to determine the correlation between nutritional status, iron intake, and fine motor development in infants aged 6-11 months.

\section{SUBJECTS AND METHOD}

\section{Study Design}

This was a cross-sectional study conducted from November 2019-January 2020 at the Community Health Centers in Kulon Progo Regency, Yogyakarta, Indonesia.

\section{Study Subjects}

The population of this study was 5,086 infants. A total of 284 infants as the study subjects aged 6-11 months were selected by purposive sampling

\section{Study Variables}

The dependent variable was fine motor development. The independent variable was nutritional status (Weight/Age) and iron intake.

\section{Operational Definition of Variables}

Nutritional status was the provision of nutrients to cells and body tissues, thus forming normal growth based on Weight/ Age.

Iron intake was the average amount of iron nutrients consumed from food in a day.

Fine motor development in infants aged 6-11 months was a movement carried out by certain body movements and only involved some of the body's muscles in infants aged 611 months.

\section{Study Instrument}

The data of nutritional status obtained using the question and answer method and observing the data of the Health Card (KMS). The data of the nutritional status in infants and the data obtained from growth charts were calculated based on the Z-Score. The data of iron intake were obtained through interviews using the 24-hour recall form that 
was carried out twice with non-consecutive days. The resulf of the 24-hour recall was converted with the Nutrisurvey application. The data of fine motor development were measured using the Prescreening Developmental Questionnaire (PDQ).

\section{Data analysis}

The data were analyzed by Chi-square.

\section{Research ethics}

This study was approved by the Health Research Ethics Commission of Sebelas

Table 1. The Characteristics of the Subjects Based on the Continuous Data

\begin{tabular}{cccccc}
\hline Variable & $\mathbf{N}$ & Mean & SD & Min. & Max. \\
\hline Age & 284 & 8.39 & 1.716 & 6 & 11 \\
\hline
\end{tabular}

Table 2. The Characteristics of the Subjects Based on the Categorical Data

\begin{tabular}{lcc}
\hline Sex & n & \% \\
\hline Male & 144 & 50.7 \\
Female & 140 & 49.3 \\
\hline
\end{tabular}

\section{The Result of the Bivariate Analysis}

Table 3 shows that 17 (6.8\%) out of 284 infants had good nutritional status but experienced fine motor development in infants
Maret University No.356/UN27.06/ KEPK/ $\mathrm{EC} / 2019$.

\section{RESULTS}

1. Sample Characteristics

Table 1 shows that the subjects obtained with a minimum age of 6 months and a maximum age of 11 months had an average of 8.39 months. Table 2 shows that there were 144 boys (50.7\%) and 140 girls (49.3\%).

Table 3. The correlation between nutritional status, iron intake, and fine motor development in infants aged 6-11 months

\begin{tabular}{|c|c|c|c|c|c|c|}
\hline \multirow{2}{*}{$\begin{array}{c}\text { Independent } \\
\text { variables }\end{array}$} & \multicolumn{2}{|c|}{ Fine Motor Development } & \multirow{2}{*}{ Total } & \multirow{2}{*}{$\mathbf{O R}$} & \multirow{2}{*}{ 95\% CI } & \multirow{2}{*}{$\mathbf{p}$} \\
\hline & Normal & Abnormal & & & & \\
\hline $\begin{array}{l}\text { Nutritional Status } \\
\text { (WAZ) }\end{array}$ & 232 (93.2\%) & $17(6.8 \%)$ & $100 \%$ & 7.12 & 3.03 to 16.73 & $<0.001$ \\
\hline $\begin{array}{ll}\text { - } & \text { Good } \\
\text { - } & \text { Poor }\end{array}$ & $23(65.7 \%)$ & $12(34.3 \%)$ & $100 \%$ & & & \\
\hline Iron Intake & & & & & & \\
\hline - Good & $53(93.0 \%)$ & $4(7.0 \%)$ & $100 \%$ & 0.61 & 0.20 to 1.83 & 0.469 \\
\hline - $\quad$ Poor & $202(89.0 \%)$ & $25(11.0 \%)$ & $100 \%$ & & & \\
\hline
\end{tabular}

\section{DISCUSSION}

In this study, there was a significant correlation between nutritional status and fine motor development in infants. However, there was a non-significant correlation between iron intake and fine motor development in infants.

Nutritional status was one of the indicators in determining the degree of child health (Widianingtyas, 2011). Infants who aged 6-11 months. 25 (11.0\%) out of 284 infants had iron deficiency and experienced obstacles in fine motor development in infants aged 6-11 months. 
was the activity of the nerve center, nerves, and muscles coordinated to carry out an activity (Sukmaningrum, 2015). These three elements were the key to fine motor movements in children. Children, who had good nutritional status, had good growth such as the growth of the brain, nerves, and muscles (Hadi, 2019). However, undernutrition status would inhibit development because it would affect the decrease in the number and size of brain cells (Yadika et al., 2019). The ability of the nervous system in the brain to make and release neurotransmitters depended on the concentration of certain nutrients in the blood obtained from the composition of food consumed by children (Febriana and Kusumaningtyas, 2018; Sukmaningrum, 2015). The three elements such as muscles, nerves, and brain coordinated to conduct fine motor movements (Yanti, 2012). Changes in motor skills in children reflected the maturity of the brain as well as muscles in children (Windasari and Hasan, 2019). The movement from the simple things to the more complex things showed a fundamental thing in the child's goal to achieve something (Solihin et al., 2013).

Iron is an essential nutrient that plays a role in motor functions (Damayanti et al., 2017). Iron plays a role in monoamine synthesis, energy metabolism in neurons and glia cells, myelination, neurotransmitter systems, and dopamine metabolism (Susanty and Margawati, 2012; Umar and Maallah, 2013). The result of this study indicated that there was no correlation between iron intake and fine motor development. It might occur due to bias while measuring iron intake in the subject using the Semi-Quantitative Food Frequency Questionnaire questionnaire (Arima et al., 2016). Bias could occur because there were some foods, especially snacks that did not include nutritional value on the label. Therefore, the way to calculate the iron content was by estimating the ingredients that might be the content of these food products (Emalia, 2015). In addition, bias could also occur because it was related to respondents' memory about the amount and frequency of food consumed by infants (Hasanah et al., 2019; Sulastri, 2012). This also occurred due to the iron intake measured was only the intake of the child especially during the first 6 months, while the nutritional intake of the mother during pregnancy in the third trimester of pregnancy was not measured (Diani and Susilawati, 2013; Susiloningtyas, 2012). In the third trimester of pregnancy, the growth and brain development began to occur so that adequate nutrition is needed especially iron and zinc (Georgieff, 2007; Prado and Dewey, 2014). Even though the result of the study showed that there was no correlation between iron intake and fine motor skills, iron deficiency in children could cause anemia. It caused fatigue, slow response, and decreased learning capability (Indartanti and Kartini, 2014; Trisnawati et al., 2017).

\section{AUTHOR CONTRIBUTION}

Catur Retno Lestari, Harsono Salimo, Adi Magna Patriadi Nuhriawangsa, made the concepts of the study, collected the data, analyzed the data, and compiled the manuscripts.

\section{CONFLICT OF INTEREST}

The authors declare that they have no conflict of interests.

\section{FUNDING AND SPONSORSHIP} None.

\section{ACKNOWLEDGEMENT}

The researchers would like to thank the Health Office and the Community Health Center of the Kulon Progo Regency who has allowed the researchers to conduct this study. 


\section{REFERENCE}

Arima LAR, Murbawani EA, Wijayanti HS (2016). Hubungan asupan zat besi heme, zat besi non-heme dan fase menstruasi dengan serum feritin remaja putri. Journal of Nutrition College, 4(2): 360-367. DOI:10.14710/jnc.v8i2.23819.

Damayanti RA, Muniroh L, Farapti F (2017). Perbedaan tingkat kecukupan zat gizi dan riwayat pemberian asi eksklusif pada balita stunting dan non stunting. Media Gizi Indonesia, 11(1): 61. https://doi.org/10.20473/mgi.v11i1.61-69.

Diani LPP, Susilawati LKPA (2013). Pengaruh dukungan suami terhadap istri yang mengalami kecemasan pada kehamilan trimester ketiga di Kabupaten Gianyar. Jurnal Psikologi Udayana, 1(1): 1-11. https://doi.org/10.24843/jpu.2013.v01.io1.po1.

Febriana A, Kusumaningtyas LE (2018). Meningkatkan motorik halus anak melalui kegiatan menganyam pada anak kelompok b usia 5-6 tahun. Jurnal UADI, 3359(18): 70-75.

Georgieff MK (2007). Nutrition and the developing brain: Nutrient priorities and measurement. Am J Clin Nutr. 85(2): 614-620. https://doi.org/10.1093/ajen/85.2.614S.

Georgieff MK (2008). The role of iron in neurodevelopment: Fetal iron deficiency and the developing hippocampus. Biochemical Society Transactions, 36(6): 1267-1271. https://doi.org/10.1042/BSTo361267.

Gunawan G, Fadlyana E, Rusmil K (2016). Hubungan status gizi dan perkembangan anak usia 1 - 2 tahun. Sari Pediatri, 13(2): 142. https://doi.org/10.14238/sp13.2.2011.142-6.

Hadi SPI (2019). Hubungan status gizi dengan perkembangan motorik pada anak usia 12-36 bulan di Desa Sambi- rejo, Kecamatan Bringin, Kabupaten Semarang. Jurnal Kebidanan Kestra. 1(2): 1-7. https://doi.org/10.35451/jkk.v1i2.126.

Hasanah WK, Mastuti NLPH, Ulfah M (2019). Hubungan praktik pemberian MP-ASI (usia awal pemberian, konsistensi, jumlah dan frekuensi) dengan status gizi bayi 7-23 bulan. Journal of Issues in Midwifery, 3(3): 56-67. https://doi.org/10.21776/ub.joim.2019.003. 03.1.

Indartanti D, Kartini A (2014). Hubungan status gizi dengan kejadian anemia pada remaja putri. hubungan status gizi dengan kejadian anemia pada remaja putri. Journal of Nutrition College. 3(2): 33-39. https://doi.org/10.14710/jnc.v3i2.5438.

Iswahyudi N, Fajar MK, Kediri UK (2019). Hubungan status gizi dengan kemampuan motorik siswa di Madrasah Tsanawiyah SE Kecamatan Rejotangan. Jurnal Koulutus. 2: 81-95.

John WS (2011). Perkembangan Anak. Jakarta: Erlangga.

Kasenda MG (2015). Hubungan status gizi dengan perkembangan motorik halus pada anak usia prasekolah di TK Gmim Solafide Kelurahan Uner Kecamatan Kawangkoan Induk Kabupaten Minahasa. Jurnal Keperawatan UNSRAT, 3(1).

McCann JC, Ames BN (2007). An overview of evidence for a causal relation between iron deficiency during development and deficits in cognitive or behavioral function. American Journal of Clinical Nutrition, 85(4): 931-945. https://doi.org/10.1093/ajcn/85.4.931

Prado EL, Dewey KG (2014). Nutrition and brain development in early life. Nutrition Reviews, 72(4): 267-284. https://doi.org/10.1111/nure.12102. 
Silsilia IW (2011). Hubungan status gizi dengan perkembangan anak. Jurnal Penelitian Kesehatan, 13(2): 142-146.

Solihin RDM, Anwar F, Sukandar D (2013). Relationship between nutritional status, cognitive development, and motor development in preschool children. The Journal of Nutrition and Food Reseacrh. 36(1): 62-72.

Sukmaningrum IA (2015). Mengembangkan ketrampilan fisik motorik halus anak melalui kegiatan menjahit untuk usia 5 - 6 tahun semester I TK Karangrejo o3 Kecamatan Wungu Kabupaten Madiun Tahun Ajaran 2015/2016. Seminar Nasional Pendidikan UNS "Meretas Sukses Publikasi Ilmiah Bidang Pendidikan". Jurnal Bereputasi. ISBN: 978979-3456-52-2.

Sulastri D (2012). Faktor determinan kejadian stunting pada anak usia sekolah di Kecamatan Lubuk Kilangan Kota Padang. Majalah Kedokteran Andalas, 36(1): 39. https://doi.org/10.22338/mka.v36.i1.p39-50.2012

Sunita A (2009). Prinsip Dasar Ilmu Gizi. Jakarta: Gramedia Pustaka Utama.

Susanty NM, Margawati A (2012). Sosial ekonomi rumah tangga dengan perkembangan motorik anak usia 24-36 bulan di wilayah kerja Puskesmas Bugangan Semarang. Journal of Nutrition College. 1(1): 327-336. https://doi.org/10.14710/jnc.v1i1.736.

Susiloningtyas I (2012). Pemberian zat besi (fe) dalam kehamilan. Majalah Ilmiah Sultan Agung. 50(128). http://jurnal.- unissula.ac.id/index.php/majalahilmiahsultanagung/article/view/74.

Sutini A, Rahmawati M (2018). Mengembangkan kemampuan motorik halus anak melalui model pembelajaran BALS. Jurnal Pendidikan Anak Usia Dini. 6(2): 49-60. DOI: 10.17509/cd.v6i2.10519.

Trisnawati E, Alamsyah D, Kurniawati A (2017). Faktor yang mempengaruhi perkembangan motorik pada anak stunting usia 3-5 tahun (Studi Kasus Di Wilayah Kerja Puskesmas Kedukul Kabupaten Sanggau). Jumantik. 5(1). DOI: 10.29406/jjum.v4i2.1274.

Umar F, Maallah MN (2013). Analyze between consumption of vegetable and Fruit with Soft Motor Development Of Children in PAUD Nusa Indah Parepare. The Russian Union Catalog of Scientific Literature (Russian). 1(1): 16. https://doi.org/10.13841/j.cnki.jxsj.2013.01.021.

Windasari, Hasan Y (2019). Penggunaan media slime untuk meningkatkan motorik halus anak cerebral palsy di SLB 1 Panti, Pasaman Timur, Padang. Indonesian Journal of Islamic Early Childhood Education, 4(1): 95-102.

Yadika ADN, Berawi KN, Nasution SH (2019). Pengaruh Stunting terhadap Perkembangan Kognitif dan Prestasi Belajar. Jurnal Majority, 8(2): 273-282.

Yanti (2012). Melalui Permainan Bola Pimpong Di Taman Kanak-Kanak Sejati Ketaping. Jurnal Pesona PAUD, 1(5): 1-12. 